\title{
Regional Anesthesia and Colorectal Cancer Surgery
}

\section{Kolorektal Kanser Cerrahisi ve Rejyonel Anestezi}

\author{
Müge Çakırca $^{1}$, Semih Başkan $^{1}$, Mehmet Çakırca ${ }^{2}$ \\ ${ }^{1}$ Ankara Numune Eğitim Ve Araştırma Hastanesi, Ankara, Türkiye \\ ${ }^{2}$ Ankara Eğitim Ve Araştırma Hastanesi, Ankara, Turkey
}

Doi:10.5505/aot.2013.07108

\section{ÖZET}

Kolorektal kanser görülme sıklığı yaşla artmaktadır. Geriatrik hastalarda kardiyorespiratuvar ve serebrovasküler sistemlerde eşlik eden hastalıklar daha sık bulunmaktadır. Bu hastalarda yüksek ASA skorları, anatomik zorluklar ve cerrahi riskler anesteziyolojist tarafindan yönetilmelidir. Anestetiklerin patofizyolojik etkilerinin daha iyi anlaşılmaya başlanması ile kolorektal kanser cerrahisi geçirecek hastaların anestezisini ve analjezisini sağlamakta rejyonel anestezi teknikleri kullanımı gündeme gelmiştir. Bu yazıda rejyonel anestezi tekniklerinin kolorektal kanser hastalarında uygulamalarının avantaj ve dezavantajları hakkında güncel bilgilerin sunulması amaçlanmıştır.

Anahtar Kelimeler: Rejyonel anestezi; kanser

\section{ABSTRACT}

The incidence of colorectal cancer increase with age. Geriatric patients have more comorbid medical conditions including cardiorespiratory and cerebrovascular diseases. Thus, high ASA scores, anatomical deformities and surgical risks should be managed by anesthesiologists. More common using of regional anesthetic tecniques to provide anesthesia and analgesia fort he patients undergoing colorectal cancer surgery has became a current issue with the better understandings on the pathophysiologic effects of the anaesthetic agents. In this article, we aimed to discuss the advantages and disadvantages of regional anesthetic tecniques in patients undergoing colorectal cancer surgery.

Key words: Regional anesthesia; cancer

\section{Kolorektal Kanserler}

Kolorektal kanser (KRK) dördüncü en s1k görülen kanser türü olup, Amerika Birlesik Devletleri'nde, kanser ile iliskili mortalite ve morbidite açısından, akciğer kanserinin ardından ikinci surada gelir (1).

Yaş, kolorektal kanser gelişmesinde önemli risk faktörüdür. Genel popülasyonda 40 yaşından sonra görülme sıklığının arttığı ve kolorektal kanserlerin yaklaş1k \%70'inin 50 yaş ve üzerinde ortaya çıktığı gösterilmiştir (2). İleri yaş, eşlik eden hastalıklar, fizyolojik kapasitenin düşmesi, ek ilaçların kullanılması gibi faktörlere bağlı olarak anestezi uygulamalarında çeşitli zorluklara sebep olabilir.

Hastaların fiziksel özelliklerindeki tedavilere bağlı anatomik değişiklikler, lenfadenopatiler, uzak metastazlar, ağrı hissinin artmış olması, var olan kateter, dren ya da diğer yabancı cisimler gibi nedenlerle işlemleri gerçekleştirmek zorlaşabilir. Kanama diyatezi ve enfeksiyona yatkınlık nedeniyle işlemlerin deneyimli kişililer tarafından yapılması, uygun koşulların hazırlanması ve olası komplikasyonlar için önlem alınması önemli konulardır (3).

Lokalize kolorektal kanserli hastalarda cerrahi birincil tedavidir. Tümörün patolojik olarak belirlenen evresi adjuvan tedavi gerekip gerekmediğini de belirler (4).

Primer tümör cerrahi olarak çıkarıldıktan sonra, ölümlerin \%90'ının sebebi metastazların varlığıdır. Cerrahi küratif olsa da immüniteyi baskılayarak önceden var olan mikrometastazların büyümesine ve tümör maniplasyonu yoluyla malign hücrelerin yayilımına sebebiyet verebilmektedir (5).

İntravenöz opioidler ve inhaler anestezikler natural killer (NK) hücrelerin aktivitesini azaltarak metastazlara katkıda bulunabilmektedir. Morfin, uygun klinik dozlarda endoteliyal proliferasyon ve anjiogenezi artırır, kanser hücresinin yaşayabilirliğini ve tümör progresyonunu 
uyarır. Bu konudaki çalışmalar, anjiogenezisin önemi sebebiyle kanser hastalarında morfin kullanımının potansiyel olarak zararlı olabileceğini gösterirler (5)

Epidural analjezi ve anestezi cerrahiye stres cevab1 azaltır ve immünitenin baskılanmasını önler. Böylece cerrahi ve genel anestezi ile oluşacak immünsupresyonu engelleyerek postoperatif enfeksiyon gelişiminden ve tümör metastazlarından hastayı korur (6). Ayrica inhale anestetikler ve opioidlere ihtiyac1 da azaltır. Opioidler intratekal kullanılsa dahi küçük miktarlarda olacağından sistemik kullanıma göre çok daha az immunsüpresiftir. $\mathrm{Bu}$ sebeplerden dolay1 epidural analjezi kanser cerrahisi geçirecek hastalar için yararlı olabilmektedir (5)

Adjuvan tedavi, mikrometastazları eradike etmek ve cerrahi rezeksiyon sonras1 iyilesme hızını arttırmak amacı ile uygulanır. Kolorektal kanserlerde adjuvan tedavinin temel ajanı, nükleotid biyosentezinde hız kısıtlayıcı enzim timidilat sentazı inhibe eden, florlu bir pirimidin olan fluorourasil (5-FU) olmaya devam etmektedir (7). Lökovorin, irinotekan, okzaliplatin diğer kullanılan ajanlardır. Kolon ile karsılastırıldığında, rektumun fizyolojik olarak fikse yapısı nedeni ile radyoterapi, rektal kanserlerin tedavisinde kullanılan bir tedavi yöntemidir (8).

\section{Kolorektal Kanserlerde Rejyonel Anestezi Teknikleri}

Kolorektal kanser cerrahisi, ileri yaş, eşlik eden hastalıklar (kardiyovasküler, respiratuar ve renal), cerrahinin büyüklüğü, süresi ve aciliyeti, genel anestezi kullanımına bağlı olarak, peri operatif 30 gün içinde kardiyorespiratuar komplikasyonlardaki artış ile ilişkili bulunmuştur (9).

ERAS (Enhanced Recovery After Surgery) ve diğer bazı gruplar epidural anestezi, preoperatif bağırsak temizliği ve nazogastrik tüp, postoperatif erken enteral nutrisyona başlama ile bağırsak fonksiyonları ve fizyolojik fonksiyonun iyileştiğini ayrıca bunların erken taburculuk sağladığını göstermişlerdir (10-12).

Epidural anestezi, pediatrik, obstetrik, jinekolojik ve ortopedik cerrahilerde başarıyla kullanılmas1 yanında, kolorektal kanser operasyonlar1 sonrasinda postoperatif analjezi sağlaması ile kritik bir rol üstlenir. Torasik epidural rejyonel anestezi, sağladığ postoperatif analjezi ile ağriya bağlı oluşan metabolik cevapları azaltarak organ disfonksiyonlarının düzelmesini sağlar (12)

Çeşitli gastrointestinal cerrahilerde yüksek kombine-spinal rejyonel anestezi uygulanan çalışmalarda erken postoperatif derlenme, etkili analjezi, mortalite ve morbiditede azalmış oranlar (\%20-40) gösterilmiştir $(13,14)$. Bu hastalarda entübasyona gerek kalmadan hastanede kalıs süresinin kısaldığı belirtilmiştir. Yüksek riskli cerrahi hastalarında mortalite ve morbiditenin önemli bir nedeni olduğu bilinen solunum komplikasyonlarının sıklığını da azalttığı gösterilmiştir (\%15.4).

Rejyonel epidural teknikler hipotansiyon, bradikardi gibi komplikasyonlara sebep olsa da ileri yaş ve blok seviyesinin yüksekliği bu komplikasyonların risk faktörü olarak belirtilmiştir $(15,16)$. Bir çalışmadaki 86 yaş ortalamasına sahip hastaların L2-4 ile T6-8 yüksek seviyesi karşılaştırıldığında oluşan komplikasyon oranının azlığı, anestetiğ uygulayan anestezistin deneyimli olmasina da bağlanmıştır. Rejyonel anestezi ile birlikte sedasyon uygulaması, ayn1 pozisyonda uzun süre kalınması ve çevreden gelen gürültünün oluşturacağı olumsuz etkileri önler. Fakat sedasyon ile uzamış derlenme, havayolu obstrüksiyonu, hipoksi ve hipotansiyon gibi morbiditeyi artıran durumlar ilişkili bulunmuștur (17).

Kombine spinal epidural anestezi tekniği, tek başına spinal ya da epidural anestezi yöntemlerinin hipotansiyon, bradikardi, bulantı-kusma, yavaş başlangıç, kullanılan yüksek doz lokal anesteziğe bağlı gelişebilecek toksisite, yamalı tutulum gibi dezavantajlarını azaltır. Bununla birlikte bu teknik; hızlı ve güvenli başlangıç, epidural kateter ile anestezi süresinin uzatılabilmesi, düşük doz ilaç kullanımıyla daha az yan etki, daha hızlı mobilizasyon ve postoperatif ağrı kontrolü gibi her iki yöntemin avantajlarını bir araya getirir. Avantajlı olmasına rağmen bu teknik kolorektal cerrahide özellikle perioperatif risklerin daha fazla olduğu geriatrik hasta grubunda henüz rutin olarak kullanılmamaktadır (18). KSE anestezi yöntemi daha çok yüksek riskli geriatrik olguları içeren kolorektal kanser cerrahisinde genel veya epidural + yüzeyel genel anesteziye alternatifolarak uygulanıp genel anestezinin 
oluşturabileceği risklerden kaçınılmasını sağlayabilir.

\section{Patofizyoloji}

Epidural analjezi perioperatif opioid analjezisi ihtiyacını azaltır ve böylece NK hücre aktivitesinin opioidlere bağlı olarak baskılanmasını engeller. NK hücreleri malign hücreleri yok etmede ve bununla ilişkili olarak metastazların önlenmesinde önemli role sahiptir (5).

Düşük perioperatif NK hücre seviyeleri kanser mortalite ve morbiditesindeki artışla ilişkili bulunmuştur (19). Epidural lokal anesteziklerle sağlanan parsiyel sempatik blokaj NK hücre aktivitesi ve lenfosit kümelerinin dağılımının düzenlenmesinde çok önemli bir role sahiptir (20). Opioidler hücresel ve humoral immün fonksiyonları baskılar, anjiyogenezisi destekler ve böylece tümörün büyümesine sebep olabilirken, epidural analjezi opiodlerin kısitlı kullanımıyla bu etkilerin önüne geçebilir (21).

İntravenöz anestezikler ve inhalasyon anestezikleri B-lenfosit fonksiyonunu bozarak apopitozu indüklerler. Hipoksi ile indüklenebilen faktör (HIF-1 alfa) düzeyini artırarak anjiyogenezisi uyarırlar ve prognozu kötüleştirebilirler (3).

Benzodiazepinler, cerrahi stresi azaltır ve santral immünmodülatuar etkileriyle sitokin salınımını azaltırlar.

Propofol, siklooksijenaz enzim inhibisyonu yapması sayesinde tümör gelişimini azaltır. Monositlerden PGE2 salınımını azaltması ve NK hücre fonksiyonlarının stabil kalmasını sağlaması önemli avantajlarıdır. Kanser hücrelerinde adhezyonu, migrasyonu ve apopitozisi azaltarak metastaz gelişimini azaltır. Beta reseptör antagonisti olması etkilerinin sebebi olabilir.

Ketaminin immünsüpresiftir, tiyopental ile ratlara verildiğinde tümör hücrelerinin yaşayabilirliğini 2-5,5 kat arttırdıkları gözlenmiştir. Proinflamatuar sitokinlerin üretimini azaltır. Makrofaj, lenfosit, mast hücre ve NK hücre fonksiyonlarını baskılayıcı özellikleri nedeniyle kötü prognostik etkileri vardır.

Tiyopental sodyum, NK hücrelerin kemotaksis özelliğini ve dolaşımdaki sayılarını azaltır. Etomidat, bazal kortizol salınımını azaltır (3).
Azot protoksit, Pürin ve timidilat sentezini değiştirerek DNA ile etkileşir, NK hücre fonksiyonunu baskılar, nötrofil kemotaksisini ve monosit üretimini bozar.

Lokal Anestezikler, sistemik olarak kullanıldıklarında antineoplastik özellik gösterdikleri bildirilmiştir. Tümör hücrelerine antiproliferatif ve sitotoksik etki ederler. Bu hücrelerden salgılanması artan endotelyal büyüme faktörünü ve hücrelerin invazyon yeteneklerini azaltırlar. Aynı zamanda mezenkimal hücre proliferasyonunu azaltır ve tümör baskılayıcı faktörleri aktive ederler $(3,22)$

\section{Rekürrens}

Rejyonel anestezi ile genel anestezi karşıaştırmalarında kanser rekkürrensinin oluşma sıklığ 1 tartışmalı bir konudur. Nöroaksiyel blokların bu konudaki rolünün tam olarak anlaşılabilmesi için ileri çalışmalara gerek vardır.

Bazı çalışmalarda perioperatif nöroaksiyel analjezi sağlanan hastalarda kanser rekürrensinin azaldığı bildirilmektedir (23-25). Gottschalk ve arkadaşları, hipotermi, kan transfüzyonu gibi rekürrensi artırdığı bilinen diğer değișkenleri düzelterek elde ettikleri sonuçlara göre çalışmalarında epidural analjezi/anestezinin rekürrens riskini azalttığını bildirmişlerdir (5).

Kolorektal cerrahi geçiren hastalarda yapılan bir başka retrospektif çalışmada ise erken bulgular kıyaslandığında, epidural anestezi uygulamasının uygulanmamasına göre rekürrens üzerinde istatistiksel olarak farkının olmadığını göstermişlerdir (23).

Uzun dönem sonuçların incelendiği mortaliteyi araştıran bir çalışmada ise epidural analjezinin rektal kanserlerde mortaliteyi azalttığ1 ancak kolon kanserlerinde etkilemediği bulunmuştur. $\mathrm{Bu}$ fark1, epidural ile önlenen nöroendokrin stres cevabın koruyucu etkisinin tümörün tipine göre değişiklik gösterebileceğine bağlamışlardır (6). Tümörün tipi, rekürrens, metastaz ve kanser ile ilişkili mortalitenin en önemli belirleyicisi olduğu vurgulanmıştır. Küçük bir çalışmada, epidural anestezinin, özefajektomi gibi majör cerrahilerde koruyucu etkisinin çok önemli olmasıyla birlikte, inflamatuar markerları baskılamada yeterli olamadığı gösterilmiştir (6). 


\section{Sonuç}

Genel anestezide kullanılan ajanların immünite, mortalite ve morbiditeye olan etkileri sıklıkla araştırılmakla beraber, rejyonel anestezi uygulamalarının kanser cerrahisinde anestezi veya analjezi amaciyla kullanılmasinın olas1 avantaj-dezavantajlarını tespit etmek bir çok araştırmacının hedefi olmuştur. Özellikle kolorektal kanserler gibi, ağrı ve anestezi kontrolü kolay olabilecek dermatomal seviyelerde gerçekleşen cerrahilerde muhtemel avantajlarına ihtiyaç vardır.

Nöroaksiyel tekniklerin tek başlarına veya genel anesteziye ek olarak kullanılmasıyla, genel anesteziklerin immünsüpresan etkileri nedeniyle metastaz oluşumu gibi oluşabilecek istenmeyen durumların önlenebilmesi amaçlanmıştır. Rekürrens konusunda tartışmalı çalışmalar yayınlanmaya devam etmekle birlikte, sağladığ 1 etkin perioperatif analjezi ile sağladıkları faydalar bu tekniklerin vazgeçilmez bir avantajı gibi gözükmektedir.

Bununla beraber, çoğunluğu geriatrik yaş grubunda olan hastalarda bu tekniklerin uygulanmasındaki sıkıntılar dezavantaj olabilmektedir. Kanama diatezine yatkınlı, anatomik bozukluklar, pozisyon vermede oluşan zorluklar sebebiyle deneyimli anestezistler tarafindan uygulanması tavsiye edilebilir.

Sonuç olarak, kolorektal kanser cerrahisi geçirecek hastalarda rejyonel anestezi-analjezi uygulamaları tek başlarına yada genel anestezi ile birlikte çeşitli faydalar sağlamakta birlikte, oluşabilecek komplikasyonlara hakim deneyimli anestezistler tarafından daha sıklıkla uygulanmalıdır.

\section{Çıkar Çatışması: Yok}

\section{Kaynaklar}

1. Jemal A, Tiwari RC, Murray $\mathrm{T}$, et al. Cancer statistics, 2004. CA Cancer J Clin 2004;54:8-29

2. Bresalier RS. Malignant neoplasms of the large intestine. In: Feldman M, Friedman LS, Sleisenger MH Editors. Gastrointestinal and liver disease, pathophysiology, diagnosis, management. Section ten. Small and large intestine.7th ed. Philadelphia. Saunders 2002;2215-62

3. Araz C. Kanser Hastalarında Anestezi. Anestezi Dergisi 2014;22:3-12

4. American Joint Committee on Cancer AHCC Cancer Staging Manual. 6th ed. New York: Springer, 2002:113-8
5. Gottschalk A, Ford JG, Regelin CC, et al. Association between Epidural Analgesia and Cancer Recurrence after Colorectal Cancer. Surgery Anesthesiology 2010;113:27-34

6. Gupta A, Fredriksson AB, Hallbo O, et al. Reduction in mortality after epidural anaesthesia and analgesia in patients undergoing rectal but not colonic cancer surgery: a retrospective analysis of data from 655 patients in Central Sweden. British Journal of Anaesthesia 2011;107:164-70

7. Sobrero A, Guglielmi A, Grossi F, et al. Mechanism of action of fluoropyrimidines:relevance to the new developments in colorectal cancer chemotherapy. Semin Oncol 2000;27:77-7

8. Bernold DM, Sinicrope FA. Advances in chemotherapy for colorectal cancer. Clin Gastroenterol Hepatol 2006;4:808-21

9. Skipworth J, Srilekha A, Raptis D, et al. Combined lumbar spinal and thoracic high-epidural regional anesthesia as an alternative to general anesthesia for high-risk patients undergoing gastrointestinal and colorectal surgery. World J Surg 2009;33:1809-14

10. Lassen K, Hannemann P, Ljungqvist O, et al. Enhanced Recovery After Surgery (ERAS) Group (2005). Patterns in current perioperative practice: survey of colorectal surgeons in five northern European countries. BMJ 330:1420-1

11. Basse L, Raskov HH, Hjort JD, et al. Accelerated postoperative recovery programme after colonic resection improves physical performance, pulmonary function and body composition. $\mathrm{Br} \quad \mathrm{J}$ Surg 2002;89:446-53

12. Basse L, Thorbol JE, Lossl K, et al. Colonic surgery with accelerated rehabilitation or conventional care. Dis Colon Rectum 2004;47:271-8

13. Lang M, Niskanen M, Miettinen P, et al. Outcome and resource utilization in gastroenterological surgery. Br J Surg 2001;88:1006-14

14. Nygren J, Hausel J, Kehlet H, et al. A comparison in five European centres of case mix, clinical management and outcomes following either conventional or fast-track perioperative care in colorectal surgery. Clin Nutr 2005;24:455-61

15. Kyokong O, Charuluxananan S, Sriprajittichai $P$, et al. The incidence and risk factors of hypotension and bradycardia associated with spinal anaesthesia. J Med Assoc Thai 2006;89:58-64

16. Carpenter RL, Caplan RA, Brown DL, et al. Incidence and risk factors for side effects of spinal anesthesia. Anesthesiology 1993;78:402-3

17. Mannion S. Sedation, spinal anesthesia and older patients. J Postgrad Med 2007;53:155

18. Boztaş N, Birlik SÖ, Akan M, et al. Kolorektal Cerrahi Uygulanan Geriyatrik Bir Olguda Kombine Spinal Epidural Anestezi. DEÜ T1p Fakültesi Dergisi 2011;25:113-7

19. Brittenden J, Heys SD, Ross J, et al. Natural killer cells and cancer. Cancer 1996;77:226-43

20. Benish M, Bartal I, Goldfarb Y, et al. Perioperative use of beta-blockers and COX-2 inhibitors may improve immune competence and reduce the risk of tumor metastasis. Ann Surg Oncol 2008;15:2042-52

21. Singleton PA, Lingen MW, Fekete MJ, et al. Methylnaltrexone inhibits opiate and VEGF-induced angiogenesis: Role of receptor transactivation. Microvasc Res 2006;72:3-11 
22. Heaney DA, Buggy J. Can anaesthetic and analgesic techniques affect cancer recurrence or metastasis? British Journal of Anaesthesia 2012;109:17-28

23. Biki B, Mascha E, Moriarty DC, et al. Anesthetic technique for radical prostatectomy surgery affects cancer recurrence: A retrospective analysis. Anesthesiology 2008;109:180-7

24. Christopherson R, James KE, Tableman M, et al. Long-term survival after colon cancer surgery: A variation associated with choice of anesthesia. AnesthAnalg 2008;107:325-32

25. Exadaktylos AK, Buggy DJ, Moriarty DC, et al. Can anesthetic technique for primary breast cancer surgery affect recurrence or metastasis? Anesthesiology 2006;105:660-4 